\title{
Barriers to Differentiation: Applying Organizational Studies to Ontario Higher Education
}

\author{
Roger Pizarro Milian \\ McMaster University \\ Scott Davies \\ University of Toronto \\ David Zarifa \\ Nipissing University
}

\begin{abstract}
Ontario's Ministry of Training, Colleges and Universities is currently attempting to increase institutional differentiation within that province's postsecondary education system. We contend that such policies aimed to trigger organizational change are likely to generate unanticipated responses. Using insights from the field of organizational studies, we anticipate four plausible responses from universities to the ministry's directives: remaining sensitive to their market demand, ceremonial compliance, continued status seeking, and isomorphism. We provide several policy recommendations that might help the ministry overcome these possible barriers to further differentiation.
\end{abstract}

\section{Résumé}

Le ministère de la Formation et des Collèges et Universités de l'Ontario cherche à accroître la différentiation institutionnelle du système d'éducation postsecondaire ontarien. Nous soutenons que les politiques publiques visant à déclencher ce changement organisationnel vont vraisemblablement engendrer des réactions imprévues. Tirant nos connaissances des champs d'études organisationnelles, nous anticipons quatre réactions potentielles aux directives du ministère par les universités. Ainsi, les universités peuvent : demeurer 
réceptives aux demandes de leur clientèle, entreprendre une conformité superficielle, s'engager dans une recherche perpétuelle d'un statut supérieur ou favoriser l'isomorphisme. Nous suggérons plusieurs recommandations de politiques publiques qui peuvent aider le ministère à faire progresser la différentiation en surmontant ces éventuels obstacles.

\section{Introduction}

In light of financial challenges caused by the economic downturn of 2008, and due to anticipated waning enrolment growth, Ontario's Ministry of Training, Colleges and Universities (MTCU) has identified "differentiation" as a key priority for its higher education system (MTCU, 2013, pp. 4-6). In a highly differentiated system, each college and university would have sufficiently distinct strategic mandates, research profiles, and academic programs. The common rationale for differentiation is to reduce unnecessary duplication, promote efficiency, and encourage effectiveness by incentivizing each institution to build on its particular, well-established strengths (Weingarten \& Deller, 2010). Through such a strategy, the ministry seeks to trigger more differentiation by having each institution craft its own unique strategic plan and subsequently ensuring that each adheres to that plan. Through this process, it hopes to reshape the structure of Ontario post-secondary education (PSE).

But how might Ontario colleges and universities respond to this initiative? Our paper ponders some possible consequences of this centralized attempt to promote more differentiation. We use insights from the field of organization studies-an interdisciplinary field of research composed of organizationally inclined sociologists, economists, political scientists, and business management scholars-to examine how change often occurs among organizations such as universities and colleges. Based on our reading of this literature, we identify four forces that are likely to mediate the MTCU's efforts to boost institutional differentiation: (1) local market demand, (2) the tendency of colleges and universities to emulate high-status universities, a process known as isomorphism, (3) the capacity of institutions to engage in ceremonial compliance rather than substantive change, and (4) the tendency of higher education organizations to engage in status seeking. Before discussing the implications of these social forces, we begin by providing a basic overview of the landscape of the Ontario PSE system, then review the current public policy discourse on differentiation in the province.

\section{The Landscape of Ontario PSE}

The Ontario PSE system is composed of four main sectors: public universities, public colleges, private religious universities, and private career colleges. Public institutions are currently the only ones that receive stable and direct financial support from the provincial government via annual operating grants. Such grants are intended to support "general educational operations," such as staff salaries and the costs of maintaining physical facilities (Snowdown and Associates, 2009, p. 19). ${ }^{1}$ Data from the 2008-2013 academic years indicate that government operating grants constitute the main source of funding for public universities, representing $48 \%$ of their overall budget. The other prime source of funds is tuition (33\%) (COU, 2014, p. 2). Ontario's 20 public universities and 24 public com- 
munity colleges educate the lion's share of the province's post-secondary students, with combined full-time enrolments of approximately $650,000,70 \%$ of which are in the university sector (Pizarro Milian \& Hicks, 2014). Public universities focus on undergraduate and graduate education and are also the main producers of scientific research within the provincial PSE system (Weingarten, Hicks, Jonker \& Smith, 2013). Community colleges focus predominantly on providing vocationally oriented certificates and diplomas (Hicks, Weingarten, Jonker \& Liu, 2013). However, several colleges, such as Humber, Sheridan, and Seneca, have recently become more like universities, granting applied degrees and conducting applied research, although their penetration into the university sector remains limited (Hicks et al, 2013; Pringle \& Huisman, 2011; Shanahan \& Jones, 2007).

There are also two private sectors in Ontario PSE that do not directly receive funds from the province, although they indirectly receive funds when their students get provincial tuition loans and grants. About 400 private career colleges share an estimated fulltime enrolment of approximately 50,000 (Pizarro Milian \& Hicks, 2014). These figures, though, do not include enrollees at a large but unknown number of unregistered institutions that are not overseen by the provincial ministry (Davies \& Taylor, 2007). Private career colleges occupy a market niche that overlaps with that of the public colleges, providing certificates and diplomas in many of the same vocational program areas. They claim to differentiate themselves from their public counterparts by offering more flexible and expedient program delivery that reduces students' time to completion. The Ontario PSE system is rounded out by 17 small, private universities that mostly specialize in theological training, although some, such as Redeemer and Tyndale, also offer degrees in other fields. Recent policy document estimate the enrolment in this last sector to be minimal (Pizarro Milian \& Hicks, 2014), perhaps only one percent of the provincial total.

\section{Differentiation in Ontario Policy Discourse}

While discussions of differentiation can be traced back to the 1970s, they re-emerged in Ontario policy discourse in 2005 (Skolnik, 2013). The MTCU document Ontario: A Leader in Learning urged the province to actively "encourage the distinct evolution of each institution" within the system "through the tuition framework, accountability arrangements and the design of the province's funding formula" (MTCU, 2005, p. 29). It called for the development of distinct missions and specialized programs while eliminating unwarranted duplication (MTCU, 2005, p. 42).

Since 2005, four more major documents have called for more differentiation in Ontario PSE. First, in Academic Transformation, Clark and his colleagues (2009) delineated a series of inefficiencies in Ontario's PSE system, describing it as "unsustainable" without further differentiation by geographic location, program, credential level, and targeted clientele (p. 138). They recommended establishing an open university, creating more online courses, founding a series of teaching-focused universities, and allowing more colleges to grant degrees. Second, The Benefits of Greater Differentiation of Ontario's University Sector (Weingarten \& Deller, 2010) described differentiation along several axes, including enrolment size, funding, programs offered, online versus traditional delivery, prestige, and student demographics. Third, Clark and colleagues' (2011) sequel publication, Academic Reform, echoed earlier calls for substantial reform to Ontario PSE. The most noteworthy element of their roadmap for change was a call for a new set of all-undergraduate, 
teaching-oriented universities. This call reflected ongoing concerns over the per-student costs of education at research-intensive universities and the tendency of these institutions to deprioritize undergraduate education in comparison to graduate training and research. Further, the authors noted the tendency of new and/or satellite universities to gradually shift their focus over time from undergraduate teaching towards research, a process that produces increased homogeneity rather than differentiation. To curb this tendency, they called for many changes, including greater numbers of teaching-stream faculty mandated to spend most of their time (80\%) on undergraduate teaching. Fourth, the MTCU's 2013 document, Ontario's Differentiation Policy Framework for Postsecondary Education, discussed how increased differentiation could help the province provide students with affordable access to a greater continuum of vocational and academic experiences despite increasingly constrained provincial budgets. This document touted differentiation as a mechanism for nurturing each institution's established strengths while guiding each to operate as a complementary part of a larger whole. It also identified several dimensions of differentiation, including meeting the needs of each local community, specializing in teaching or research/graduate education, and creating unique programs.

These four documents have been complemented by two others produced by the Higher Education Quality Council of Ontario (HEQCO) (Hicks et al., 2013; Weingarten et al., 2013) that aimed to clarify the meaning of differentiation. One framed differentiation among public universities in terms of research intensiveness and comprehensiveness. It described the University of Toronto as being in its own league, competing with other top universities across the world, followed by a cluster of research-intensive universities consisting of McMaster, Western, Waterloo, Ottawa, Queen's, and Guelph. It then described a group of primarily undergraduate universities: Algoma, Nipissing, UOIT, Laurier, Trent, Brock, Lakehead, and Laurentian. Sandwiched between these two groups were universities that did not fit neatly into either research or undergraduate clusters: York, Carleton, Windsor, and Ryerson. The other document framed differentiation among public community colleges in terms of program diversity and participation in degree granting. It grouped colleges that are very engaged in degree granting-Seneca, Sheridan, George Brown, and Humber-versus others that are far less involved.

\section{Analytical Methods}

In the next section we draw on recent theoretical and empirical work within the interdisciplinary field of organizational studies to anticipate some social processes that could be triggered by government attempts to boost institutional differentiation among its public universities. Since this is an analytical essay, we do not utilize any unique data sources but instead draw on key theories from a large literature, particularly foundational and recent texts in the new institutional (DiMaggio \& Powell, 1983; Meyer \& Rowan, 1977; Scott, 2008) and resource dependency (Pfeffer \& Salancik, 1978) traditions. Both of these theoretical perspectives adopt what have been termed open systems approaches to understanding organizational behaviour (Scott, 2008). Like Canadian work on PSE (e.g., Fisher et al., 2006; Jones, 2004; Pringle \& Huisman, 2011; Shanahan \& Jones, 2007), they acknowledge the influence of regulatory bodies on organizational behaviour but also emphasize other factors that are sometimes ignored by policy makers, such as organizational prestige, professional and cultural norms (Quirke, 2013), and various strategies by 
which organizations might evade full compliance with externally imposed policies (Oliver, 1991; 1992). We complement these theoretical discussions with illustrative studies from contemporary education research in order to provide prominent examples from Canada and other jurisdictions, mostly the United States and Britain. We attempt to synthesize insights from organizational theory with key empirical studies to provide a prognosis of likely events if the province proceeds with its differentiation policy.

Policy discourse on differentiation has highlighted many of its potential benefits yet has focused far less on unanticipated but plausible reactions by Ontario colleges and universities to such initiatives. Below we identify some possible dynamics that could be set in motion by such central directives and conclude with several recommendations for central authorities to reduce these potential barriers to differentiation.

\section{The Nature of Student Demand: Market Forces in Higher Education}

Attempts to change organizations against the flow of market demand, no matter how rational or justified they may appear to policy makers, can produce undesired results. Educational historians and sociologists have long catalogued various kinds of failures in centrally planned educational expansion, whether in Canada (Fleming, 1971), the United States (Brint, Proctor, Murphy, \& Hanneman, 2012; Kraatz \& Zajac, 1996; Labaree, 1997, 2012), or Britain (Wolf, 2003, 2011). Despite looking at a diverse array of historical periods and regulatory environments, each of these analyses suggests that central planning by government and/or institutional leaders can be stymied if it is not sufficiently aligned with the wants of educational consumers.

In Canada, the rise and fall of Ontario technical institutes in the 1940s, 1950s, and 1960 is a prime example. During this period, the province established these institutes to provide training that was more specialized and applied than that offered by universities. But due to minimal popular demand, these institutes never captured a considerable share of the PSE student market. By 1963, they had enrolled only 4,000 students (Skolnik, 2010, p. 4), and by 1965, this figure had shrunk to approximately 2,500 (Fleming, 1971, p. 452). This lack of demand severely limited their lifespan. Their failure was eventually corrected by policies that reshaped technical institutes into entities that more closely resembled today's community colleges and universities. For example, the Provincial Institute of Mining and the Northern Ontario Institute of Technology were absorbed during the creation of St. Clair College (Fleming, 1971, p. 522). Similarly, the Provincial Institute of Trades and the Provincial Institute of Trades and Occupations were brought together to found George Brown College (Fleming, 1971, p. 522). Meanwhile, others such as Lakehead Technical Institute and the Ryerson Institute of Technology were eventually revamped into universities. These transformations were necessitated by public demand for "broader" institutions rather than narrower technical alternatives to universities (Skolnik, 2010, p. 4).

In the United Kingdom, Wolf $(2003,2011)$ has similarly documented how policy makers' attempts to increase participation in vocational training failed due to misalignment with student and parent preferences. Despite the introduction of new National Vocational Qualifications (NVQs) during the 1990s, students continued to opt for more traditional academic credentials. A decade later, half of all NVQs had effectively gone unused: 364 had never been awarded to a single candidate, while another 43 had each been awarded to only a single individual. Many others fell short of double figures. In response to such 
dismal failure, policy makers crafted a more general NVQ that more closely resembled academic A-levels, desired by most UK students (Wolf, 2003, pp. 75-76). This more academic credential generated a much more favourable response from students. More recently, Wolf (2011, p. 9) has continued to characterize British attempts to centrally plan vocational education as "inherently ineffective" and "expensive and counterproductive" (p. 21). She faulted the central government's constant redesign, re-regulation and reorganization of vocational education for being disconnected from both labour-market and PSE demand. Wolf found that innovative and successful vocational credentials were created when planning and design of those credentials was delegated to local levels. This decentralized decision making, she suggested, allowed institutions to more effectively respond to changing labour markets and to local employers ${ }^{2}$ who had a stake in vocational education. Their direct input ensured that courses and qualifications had genuine labourmarket value and credibility.

The American experience also offers plenty of examples of centrally planned change being thwarted by market forces. Looking far back in history, Labaree (1997) noted how the imported German research university model lessened the popularity of the pre-existing American land-grant college, which had focused almost exclusively on teaching and vocational skills training. The new research university was soon seen to offer an "upper track" that provided access to attractive social positions and was thereby compatible with (North) American values of opportunity and upward mobility. As many students and educators were reluctant to settle for "lower-track" college programs, their demand for vocational-oriented training waned, driving land-grant universities and colleges to become isomorphic with their new counterparts by offering more academic and professional credentials and by conducting research.

Looking at more recent American history, Labaree (2012) has seen much evidence that consumers, much more than central decision makers, eventually dictate the shape of higher education. For instance, many private liberal arts colleges and other institutions have gradually shifted their programs in more vocational and professional directions, away from their traditional missions, in response to consumer preferences (see Brint, Riddle, \& Hanneman, 2006; Brint, Proctor, Murphy, Turk-Bicakci, \& Hanneman, 2009; Kraatz \& Zajac, 1996). The internal structures of higher status universities are also strongly shaped by students' non-academic preferences. In a recent case study of a relatively high-status Midwest university, Armstrong and Hamilton (2013) showed how the institution catered to students with the strongest family connections and financial resources by supporting a variety of non-academic organizations such as fraternities, sororities, and other clubs, and by attempting to maintain a vibrant social atmosphere on campus. By contrast, lower status universities cater mostly to students of lower socioeconomic status by focusing less on social organizations and more on applied and vocational programs (for other examples of such contrasts in US higher education, see also Mullen [2010] and Stuber [2011]).

Beyond consumer preferences, PSE organizations are also sensitive to any shifts in other revenue streams, and such shifts can undermine centrally planned change. Steven Brint and his colleagues found that selective institutions with large endowments can insulate themselves from changing consumer preferences and respond instead to the demands of wealthy private donors (see Brint, 2013; Brint et al., 2011). This finding is important because Ontario post-secondary institutions have multiple revenue sources beyond the 
MTCU. While the ministry is the largest direct funder of Ontario's public universities, figures from the 2008-2013 academic years show that less than half of their income now comes from government operating grants (COU, 2014). Even though the overall proportion of funding from private donations remains small, today the names of wealthy donors are commonly displayed on the walls of university buildings and laboratories; those funds are highly sought after at the margins of institutional budgets and are used to leverage new directions on campuses.

In Ontario PSE, geography also clearly shapes student preferences. Proportionately few Ontario students move across regions to attend university and colleges compared to those in countries such as the United States. For example, Davies, Maldonado, and Zarifa (2014) found that $62 \%$ of the Toronto District School Board (TDSB) graduates who went on to university remained in Toronto, and another quarter attended relatively high-status universities near the city, such as Guelph, Waterloo, Western, and McMaster. Only one percent attended universities in further locales such as Nipissing, Lakehead, Laurentian, or Windsor. An earlier study by Drewes and Michael (2006) on institutional selection within Ontario observed similar dynamics. They found that students' ranked preferences were strongly influenced by spatial proximity. Much anecdotal evidence suggests that a large proportion of Ontario's college and university students are commuters. ${ }^{3}$

These considerations are important if calls for differentiation lead to sizeable reductions in program duplication across institutions and if more students are expected to travel longer distances for certain programs. Since much of the demand for higher education in the province is local in nature, many potential undergraduates may be unwilling to travel long distances even for quite specialized fields. In a recent study of interdisciplinary programs in the United States, Jacobs (2013) found that many new academic units, even those touted as lying at the cutting edge of innovation, soon closed because they failed to capture student demand, or they were unable to attract private funders after a few years of operation. Thus, if differentiation entails having more institutions offer more specialized credentials, this policy could be undermined by students who want more general degrees and diplomas and/or are unwilling to travel long distances.

\section{Isomorphic Forces}

Leaders of organizations in a variety of fields typically confront pressures to change while lacking the kinds of information that might facilitate rational and efficiency-seeking decisions (Nelson \& Winters, 1982; Simon, 2000; Spiegler, 2011). Higher education is one such field. Universities and colleges operate with a great deal of uncertainty. Rather than having a singular goal, such as selling a profitable product, they are complex organizations with multiple goals and activities, most notably including teaching, research, and public service (Bastedo, 2007; Stevens, Armstrong, \& Arum, 2008). Their constituents want them not only to produce graduates with marketable skills that stimulate local economies, but also to be conduits of equal opportunity that nurture good citizens and enhance their community settings. But success at meeting these goals is often difficult to measure. Whereas an automaker can easily count the number of cars it produces and assess whether they are profitable, it is far more difficult for colleges and universities to assess whether their instruction has added value to their graduates' skill sets and capabilities, never mind their aptitudes for citizenship and community 
engagement. While $\mathrm{K}-12$ schools assess some of their goals using standardized tests for foundational skills in math, reading, and writing, higher education lacks an agreed upon set of metrics that could demonstrate its impact on students. Accordingly, rather than closely regulating and monitoring their teaching, colleges and universities instead rely on a logic of confidence (Meyer \& Rowan, 1977), in which instructors that have appropriate credentials are hired and are presumed to be doing their jobs unless some extreme information to the contrary arises. Such conditions tend not to reward colleges and universities for efficient and effective completion of tasks. Rather, these conditions reward them for acting in ways perceived to be legitimate according to their institutional environment (DiMaggio \& Powell, 1983; Meyer \& Rowan, 1977), that is, the norms of their field. New institutional theory highlights several forces by which organizational change occurs under these conditions.

The first such force is termed mimetic isomorphism. In environments that lack clearly effective and efficient practices, decision makers typically mimic peer organizations they perceive to be successful (Mizruchi \& Fein, 1999, p. 657; see also DiMaggio \& Powell, 1983; Scott, 2008). Following this logic, Ontario universities that are research intensive, or wish to become so, will mimic high-status institutions like the University of Toronto and Queen's University. In turn, the University of Toronto and Queen's will emulate global superstars such as Harvard, Yale, Oxford, or Stanford. This mimicry has been documented repeatedly in American PSE. While small state colleges rarely directly emulate Harvard, there is a broad tendency for institutions to follow the directives of organizations they consider to be their peers, whether in terms of mandate, organizational type, resource capacity, or status. Scott (2010, p. 12) highlights how less well-endowed schools doggedly follow directions set by more prestigious colleges. Brint, Riddle, and Hanneman (2006) also found that presidents of less prestigious four-year universities and colleges emulated their more prestigious counterparts by adopting comprehensive forms and increasing research intensiveness and graduate training. This isomorphism tends eventually to lessen the aggregate amount of differentiation within PSE systems (for another US example, see Tuchman [2009]).

Mimetic isomorphism appears to be encouraging PSE organizations to aspire for university status and even to become research universities. For instance, despite MTCU's call for universities to showcase their institutional differences in their strategic mandate agreements (SMAs), most universities, whether research-intensive or comprehensive, produced SMAs that were surprisingly similar (HEQCO, 2013). One source of this unanticipated uniformity may be the status that is associated with conducting research. Applications to the Postsecondary Education Quality Assessment Board (PEQAB) show that more and more colleges, such as Sheridan, are crossing sector boundaries and slowly transforming themselves into universities, following a route already paved by OCAD University and Ryerson. The latter has greatly expanded its graduate programs and research activity over the past decade, as have Laurier, Brock, and some other institutions that were primarily undergraduate institutions. Weingarten and Deller (2010) view this type of mandate creep negatively, warning that it leads to unnecessary and inefficient program duplication. Despite such criticism, these tendencies towards isomorphism are difficult to stop as long as institutions seek to raise their status (we will return to this line of reasoning in a later section). 
Organizational change also occurs through what organizational researchers call normative isomorphism. This isomorphism is a product of the distinctive values, beliefs, and world views of professionals. Similar training in professional schools and graduate programs tends to forge shared norms among their graduates (Mizruchi \& Fein, 1999; Morrill \& McKee, 1993). These norms become embodied and enacted in professional organizations such as the College of Physicians and Surgeons of Ontario, the Law Society of Upper Canada, the Ontario Dental Association, and all sorts of academic associations, and have become quite institutionalized and taken for granted in the province. Almost all professors and academic administrators in universities are members of these professional bodies. Being well versed in professional academic norms, most continue to value conventions such as faculty research, academic freedom, liberal educational ideals, and tenure. These norms shape administrators' implicit image of the ideal university and college and inform how they pursue organizational change, including decisions on what type of departments should continue to exist. Budros (2002), in a study of financial retrenchment in Ontario universities, found that presidents who lacked backgrounds in business and/or economics and did not have corporate connections were less likely to adopt costsaving reforms. Many professors, including administrators, often associate traditional liberal arts programs with the spirit, soul, purpose, and dignity of the ideal university and decry vocational training, careerism, and technological specialization (Gustafson 2009; Kraatz \& Zajac, 1996; Leathwood \& Hutchings, 2003). Any promotion of differentiation would need to partially align with these powerful professional norms. As evidence, Jacobs (2013) pointed to numerous examples of collegial reactions that have limited the number of departmental closures in US universities and colleges. He found that in addition to professors and students who are directly affected by closures, colleagues from far-flung disciplines and even other institutions have also reacted publicly, arguing that such losses damage the ecology of entire institutions. These reactions have sometimes forced administrators to reverse their previous decisions.

Coercive isomorphism is a third process that tends to hinder differentiation (DiMaggio \& Powell, 1983; Scott, 2008). Coercion refers to pressures generated by an actor's dependency on financial resources and on central regulations. For instance, regulatory and funding arrangements often demand that various kinds of structures and practices be implemented in all organizations. One current example is the Ministry of Education's mandate in Ontario to cut teachers' college enrolments by half and double the program duration from one to two years by 2015 (Alphonso, Morrow, \& Bradshaw, 2013). This ministry-initiated reform has quickly changed existing practices for all teachers' colleges alike. As another example, the federal government's research councils (SSHRC, NSERC, CIHR) have over the decades leveraged the erection of internal supporting structures (research offices, ethics committees, and the like) and procedures (ranking of doctoral applicants, ethics procedures) that are similar across universities; without them, such bodies would probably vary more across institutions and may even be entirely absent from some. Importantly, such central pressures usually serve to make organizations more similar to one another. MTCU's promotion of differentiation is an interesting central initiative that is aimed in the opposite direction-to make organizations more dissimilar from one another.

Sometimes coercive initiatives are met by resistance when they run against the grain of longstanding practices. For instance, Hallett (2010) describes the turmoil in a Midwest 
elementary school that resulted from faculty resistance to an externally imposed accountability scheme. While the reform was implemented to raise student test scores, teachers saw it as a threat to their autonomy and worked to thwart many directives prescribed by that policy. Sometimes coercion has only a partial impact in complex fields such as PSE, in which universities have multiple resource dependencies that tend to weaken the strength of any single coercive push from a central actor (Levy, 2006). MTCU lacks a monopoly on this type of force; as mentioned earlier, students can "vote with their feet" in response to any unwanted organizational change, as can corporate donors and federal government granters (Fisher et al., 2006). Beyond direct resistance and multiple resource dependencies, actors who receive central directives can undermine them using a variety of softer methods, some of which we describe next.

\section{Ceremonial Compliance}

Researchers have long emphasized organizations' tendencies to be structurally inert, particularly older enterprises that lack innovative capacity to quickly change course (Hannan \& Freeman, 1984; Le Mens, Hannan, \& Polos, 2014). But inertia can sometimes assume a hidden form when organizations appear to respond to external coercive pressures without greatly altering their core practices. One typical strategy is known as concealment, in which organizations simply disguise their intention to not implement change (Oliver, 1992, pp. 154-155). In the business world, corporations can display non-routine activities during inspections by external stakeholders, such as government agencies, by deferring upkeep of physical plants until immediately before scheduled inspections, thus maintaining an impression of constant upkeep (Jackall, 1988, p. 23).

In education, organizational researchers refer to a similar but more subtle and symbolic process known as ceremonial compliance. Organizations can change their formal structures in order to create the appearance of change and to signal conformity to external dictates, but then allow their internal units to operate as before, largely independently of these dictates (Hallet, 2010; Scott, 2008). For instance, one simple method by which institutions align with new directives, but mainly only on the surface, is to rename old organizational components, often simply by putting new labels on old courses or programs (see Tyack \& Cuban, 1995, p. 79). This can be partly seen in universities' pursuit of all kinds of interdisciplinary studies over the past two decades. In response to a variety of pressures, universities have established numerous centres and institutes in areas ranging from nanotechnology to globalization to cultural studies. Some are vital, active, well-resourced bodies. But others are largely shadow constructs, borrowing staff, faculty, and courses from existing departments. Their websites and brochures can make them appear substantial despite many of their affiliates playing little in the way of active roles, and despite them occupying little or no physical space. Some of these centres and institutes appear to be exercises in organizational impression management more than deep, substantive change.

A similar organizational practice is known as loose coupling or decoupling. This practice enables organizations to alter their public facades or formal structures to align with central directives, while at the same time allowing ground-level actors leeway to use their own discretion to adapt (or not) to change and to local circumstances (Meyer \& Rowan, 1977; Weick, 1976). Loose coupling is a mechanism by which organizations can comply 
with central directives formally while continuing with their existing practices. To signal change, universities readily alter the names of academic units rather than their core practices, since changing labels is much easier than overhauling established activities; studies have documented examples of units changing their name numerous times over a single decade (Jacobs, 2013). Colleges and universities can formally rebrand themselves by relabeling old courses, creating new credentials while retaining their core structures and underlying practices.

\section{Status Seeking}

Another key dynamic that can buffer against the influence of any differentiation policy is status seeking. Most Ontario universities are non-profit entities that adhere to academic norms. Competition between institutions within that field tends to be driven not only by resource scarcity, but also by notions of prestige, reputation, and status (Davies \& Pizarro Milian, forthcoming). Status hierarchies emerge both between and within broad categories of institutions (by size, region, age, and research intensiveness). These hierarchies may be contested, but they tend to endure, and in older systems such as those in the United States, they have a long history. Indeed, status competition between universities has intensified in recent years due to a combination of more complex resource dependencies (i.e., organizations need to pursue multiple revenue streams rather than relying mainly on a single source) and because the means by which they compete has become more rationalized.

One mechanism that has rationalized status competition is the visibility of published rankings of universities. Over the past two decades, Maclean's rankings, along with various international rankings, have gained prominence in Canada (Drewes \& Michael, 2006; Pringle \& Huisman, 2011). Even though many actors continually denounce, decry, or mock these rankings, they have gained visibility with time. One reason may be that rankings are a simple means to generate images of an institution's status. They offer applicants, alumni, and donors a single metric to summarize a multitude of qualitative differences between universities. This power to generate external images of universities tends to reshape their organizational practices, even among administrators who may be sharply sceptical of their validity, affecting how they define goals, assess progress, recruit and evaluate peers and students, forge new programs, and budget their resources (Espeland \& Sauder, 2007). In the United States, some administrators claim that "[rankings] are always in the back of everybody's head. With every issue that comes up we have to ask, 'How is this impacting our ranking?"' (Espeland \& Sauder, 2007, p. 11). Some universities redistribute their resources to manipulate their scores in prominent ranking schemes. As one dean stated: "It would be stupid in a competitive environment not to do the things that are better for the US News" rankings (Sauder \& Lancaster, 2006, p. 131). At the extreme, institutions engage in gaming strategies in attempts to rig measures and raise their rank (for examples, see Stevens, 2009), particularly when downward slides prompt alarm from alumni, students, local media, and faculty.

These practices are not restricted to the United States (Hazelkorn, 2009), although Canadian findings on the influence of rankings are mixed. Canadian students appear to consult rankings when selecting among relatively less known and small universities (Drewes \& Michael, 2006), and rankings appear to partly influence students' decisions 
when they are selecting among large research universities (Kong \& Veall, 2005). But anecdotal evidence hints that administrators are sensitive to any drops in their institution's rank. When Brock fell down the rankings in 2011 after moving up to the comprehensive category, its provost lamented that "you have to have realistic expectations," that it was their "first year being compared in this senior category" (Brock University, 2011). Even dismissive public statements about rankings from university leaders illustrate their sensitivity to their institutional image. As one has stated: "We are concerned about Maclean's rankings and our reputation ... the outside environment has made us sensitive to this, and these pressures have become internalized" (Crocker \& Usher, 2006, p. 10). Canadian universities that are highly ranked internationally, like the University of Toronto, regularly announce their success in the rankings in promotional material.

Our point is that any preoccupation with rankings, prestige and status can pose a significant barrier to differentiation. If status competitions tend to reward institutions for having certain practices and structures, many institutions will strive to adopt those practices and structures. For example, if the Maclean's rankings give much weight to winning Tri-Council research grants, institutions will be incentivized to boost their research capacity and perhaps de-emphasize their undergraduate teaching. In such scenarios, status hierarchies could promote homogeneity rather than differentiation.

\section{Promoting Conditions in Favour of Differentiation}

Organizations do sometimes drop traditional practices and comply with centrally directed change. External shocks can drive organizations to reconsider their institutionalized practices, particularly those that are visibly failing (Oliver, 1992). For instance, universities will (albeit reluctantly) close academic programs with tiny enrolments. Moreover, significant employee turnover, leader succession, and increases in workforce diversity can promote slow change by disrupting internal norms and organizational traditions. Newcomers bring different interpretive frameworks and practices that can diminish consensus and the taken-for-granted character of longstanding practices (Oliver, 1992, p. 575). In Canadian PSE, Crocker \& Usher (2006, p. 6) document the tendency of universities with younger faculty, who are less entrenched in traditional academic norms and practices, to have better "climates for innovation."

Similarly, the MTCU could ease the pressures of normative isomorphism on university administrators by staging system-wide workshops and seminars about differentiation and its potential benefits. But importantly, administrators should work with disciplinary representatives-key purveyors of normative isomorphism-to ponder their possible futures in Ontario PSE, allowing them to voice their concerns; otherwise, they may simply resist change.

To promote differentiation, the MTCU could also attempt to lessen the influence of rankings by providing alternative incentives for colleges and universities to attain status along additional dimensions. If single ranking schemes cause status hierarchies to coalesce, multiple schemes can create more ambiguity about the relative standing of schools. This ambiguity could reduce the significance of small differences between ranks and even undermine their validity (Sauder \& Espeland, 2006, p. 206). Multiple, crosscutting status dimensions could instead encourage each institution to nurture its own unique reputation. This point speaks to differentiation policies that aim to reverse current ten- 
dencies for universities to prioritize research intensity over undergraduate teaching. Most rankings currently tend to reward research. But a more pluralistic status system could encourage diversity by lessening pressures on mid- to low-rank universities to conform to prevailing normative pressures in the form of emulating research universities. Beyond the sheer compulsion of seeking tuition dollars, those institutions could be encouraged to prioritize their undergraduate teaching if it were further associated with time-honoured liberal arts ideals rather than just resource efficiencies. ${ }^{4}$ Quite simply, lower ranked institutions may be more inclined to differentiate their mandates if any changes are seen to be consistent with their pursuit of upward mobility and status.

Better interpretations of student preferences might also lower barriers to differentiation. While MTCU already studies market forces in many ways, it may wish to develop new data sources. Administrators' and policy makers' information about student demand is lagged and imperfect. Existing administrative data from students' ranked choices (e.g., Ontario Universities' Application Centre data; see Drewes \& Michael, 2006) has the limitation of reflecting only existing arrangements in Ontario PSE rather than student preferences for potential institutions and/or programs. For instance, a Greater Toronto Area student who desires to enter engineering but currently lacks the grades to be accepted into the University of Toronto's program might consider attending a new or expanded engineering program nearby at Ryerson or York but not at a more distant location such as Lakehead or Windsor. Surveys could be used to gauge such untapped demand among high school students by probing preferences for different combinations of programs, institutions, and locales. Those data might facilitate the development of differentiation strategies that are closely attuned to the wants of prospective students.

\section{Conclusion}

Reshaping the structure of Ontario PSE will not be an easy task. Multiple organizational processes actively work against differentiation, and so the trajectories of any such policy are difficult to predict. Our review of organizational studies in higher education suggests that successful efforts to promote differentiation will likely need to closely align with consumer wants and also work in concert with prevailing mimetic, normative, and coercive forces that are currently promoting isomorphism. Reforms tend to stick and spark change if they are compatible with existing practices and norms. To encourage universities to really change rather than comply in mere ceremonial fashion, central directives should be compatible with prevailing academic norms and organizational practices, including those that are oriented towards the pursuit of institutional status. This recommendation cannot ensure a seamless road towards a more differentiated Ontario PSE system, but it might reduce any potential conflicts by developing policy that can redirect the powerful forces that are currently encouraging isomorphism.

\section{Notes}

1. Such funding has explicitly excluded funding activities associated with sponsored research, interest payments, student financial aid, and ancillary enterprises/capital projects (MTCU, 2009, p. 1).

2 Here, Wolf (2011) highlights a benefit of loose coupling to which both early (Weick, 1976) and contemporary (Aurini, 2012; Ethiraj \& Levinthal, 2004; Hallet, 2010; Rav- 
asi \& Verona, 2001) theorizing within organization studies have alluded. Loose coupling allows actors on the ground to broadly comply with policies while feeling out and adapting to local conditions. We develop this argument further below.

3 Redeemer University College, for example, acknowledges on its website that approximately half of its students commute to its campus. Other universities, such as York, Ryerson, and McMaster, are also regularly referred to as having commuter campuses.

4 At the K-12 level, Quirke (2013) found that newer Toronto private schools that sought legitimacy without having bountiful resources often did so by embracing liberal arts ideals, relatively small classes, and a customer-oriented ethos.

\section{Acknowledgements}

Financial support for this research was provided by the Ministry of Training, Colleges and Universities through their Ontario Human Capital Research and Innovation Fund. The views expressed in this paper are those of the authors and do not necessarily reflect those of the Ministry.

\section{References}

Alphonso, C., Morrow, A., \& Bradshaw, J. (2013, June 5). Ontario moves to halve number of teacher's college graduates. The Globe and Mail. Retrieved from http://www. theglobeandmail.com/news/national/ontario-moves-to-halve-number-of-teacherscollege-grads/article12357404/

Armstrong, E., \& Hamilton, L. (2013). Paying for the party: How college maintains inequality. Cambridge, MA: Harvard University Press.

Aurini, Janice. (2012). Patterns of loose and tight coupling in a competitive private education marketplace: the case of learning center franchises. Sociology of Education, 85(4), 376-390.

Bastedo, M. N. (2007). Sociological frameworks for higher education policy research. In P. Gumport (Ed.), Sociology of higher education: Contributions and their contexts (pp. 295-316). Baltimore, MD: The Johns Hopkins University Press.

Brint, S. (2013). A priori and empirical approaches to the classification of higher education institutions: The U.S. Case. Pensamiento Educativo, 5o(1), 96-114.

Brint, S., Proctor, K., Murphy, S. P., \& Hanneman, R. A. (2012). The market model and the growth and decline of academic fields in US four-year colleges and universities, 1980-2001. Sociological Forum, 27(2), 275-299.

Brint, S., Proctor, K., Murphy, S. P., Turk-Bicakci, L., \& Hanneman, R. A. (2009). General education models: Continuity and change in the US undergraduate curriculum, 1975-2000. The Journal of Higher Education, 8o(6), 605-642.

Brint, S., Riddle, M., \& Hanneman, R. A. (2006). Reference sets, identities, and aspirations in a complex organizational field: The case of American four-year colleges and universities. Sociology of Education, 79(3), 229-252.

Brint, S., Riddle, M., Turk-Bicakci, L., \& Levy, C. S. (2005). From the liberal to the practical arts in American colleges and universities: Organizational analysis and curricular change. The Journal of Higher Education, 76(2), 151-180. 
Brock University. (2011, 28 October). Maclean's 2011: The good, the bad and the ugly. The Brock News. Retrieved from http://www.brocku.ca/brock-news/?p=13183

Budros, A. (2002). Do university presidents make a difference? A strategic leadership theory of university retrenchment. Canadian Journal of Higher Education, 32(1), 91-124.

Clark, I. D., Moran, G., Skolnik, M. L., \& Trick, D. (2009). Academic transformation: The forces reshaping higher education in Ontario. Montréal, QC: McGill-Queen's University Press.

Clark, I. D., Trick, D., \& Van Loon, R. (2011). Academic reform: Policy options for improving quality and cost-effectiveness of undergraduate education in Canada. Montréal, QC: McGill-Queen's University Press.

Council of Ontario Universities (COU). (2014). Financial Report of Ontario Universities 2012-13 Highlights. Retrieved from http://cou.on.ca/wp-content/uploads/2015/o4/ Financial-Report-Highlights-2012-13.pdf

Crocker, R. K., \& Usher, A. (2006). Innovation and Differentiation in Canada's Postsecondary Institutions. Canadian Policy Research Networks. Retrieved from http:// rcrpp.ca/documents/43887_en.pdf

Davies, S., Maldonado, V., \& Zarifa, D. (2014). Effectively Maintaining Inequality in Toronto: Predicting Student Destinations in Ontario Universities. Canadian Review of Sociology, 51(1), 22-53.

Davies, S. \& Pizarro Milian, R. (forthcoming). Maintaining Status in Times of Change: The Continuing Stratification of Anglo-American Universities. In Cote, J. \& Furlong, A. (Eds.), The Routledge Handbook of the Sociology of Higher Education. Routledge International Books.

Davies, S. \& Taylor, A. (2007). A profile of Private post secondary providers in Canada. Report for the Canadian Council on Learning.

DiMaggio, P., \& Powell, W. W. (1983). The iron cage revisited: Institutional isomorphism and collective rationality in organizational fields. American Sociological Review, 48(2), 147-160.

Drewes, T., \& Michael, C. (2006). How do students choose a university?: An analysis of applications to universities in Ontario, Canada. Research in Higher Education, 47(7), 781-800.

Espeland, W. N., \& Sauder, M. (2007). Rankings and reactivity: How public measures recreate social worlds. American Journal of Sociology, 113(1), 1-40.

Ethiraj, S. K., \& Levinthal, D. (2004). Bounded rationality and the search for organizational architecture: An evolutionary perspective on the design of organizations and their evolvability. Administrative Science Quarterly, 49(3), 404-437.

Finkelstein, S. (1997). Interindustry merger patterns and resource dependence: A replication and extension of Pfeffer (1972). Strategic Management Journal, 18(10), 787-810.

Fisher, D., Rubenson, K., Bernatchez, J., Clift, R., Jones, G., Lee, J., . . Trottier, C. (2006). Canadian federal policy and postsecondary education. Vancouver, BC: Centre for Policy Studies in Higher Education and Training, University of British Columbia. 
Fleming, W. G. (1971). Ontario's educative society. Vol. 4: Postsecondary and adult education. Toronto, ON: University of Toronto Press.

Gustafson, J. (2009). Entrepreneurship as a liberal art. In P. West III, E. J. Gatewood, \& K. Shaver (Eds.), Handbook of university-wide entrepreneurship education (pp. 6070). Cheltenham, UK: Edward Elgar Publishing.

Hallett, T. (2010). The myth incarnate: Recoupling processes, turmoil, and inhabited institutions in an urban elementary school. American Sociological Review, 75(1), 52-74.

Hannan, M. T., \& Freeman, J. (1984). Structural inertia and organizational change. American Sociological Review, 49(2), 149-164.

Hazelkorn, E. (2009). Rankings and the battle for world-class excellence. Higher Education Management and Policy, 21(1), 1-22.

Hicks, M., Weingarten, H. P., Jonker, L., \& Liu, S. (2013). THE DIVERSITY OF ONTARIO'S COLLEGES: A Data Set to Inform the Differentiation.

Higher Education Quality Council of Ontario (HECQO). (2013). Quality: Shifting the focus. Retrieved from http://www.heqco.ca/SiteCollectionDocuments/FINAL\%20 SMA\%2oReport.pdf

Jackall, R. (1988). Moral Mazes; The World of Corporate Managers. New York, NY: Oxford University Press.

Jacobs, J. (2013). In defense of disciplines: Interdisciplinarity and specialization in the research university. Chicago, IL: University of Chicago Press.

Jones, G. A. (2004). Ontario higher education reform, 1995-2003: From modest modifications to policy reform. Canadian Journal of Higher Education, 34(3), 39-54.

Kong, Q., \& Veall, M. R. (2005). Does the "Maclean's" Ranking Matter? Canadian Public Policy/Analyse de Politiques, 31(3), 231-242.

Kraatz, M. S., \& Zajac, E. J. (1996). Exploring the limits of the new institutionalism: The causes and consequences of illegitimate organizational change. American Sociological Review, 61(5), 812-836.

Labaree, D. F. (1997). How to succeed in school without really learning: The credentials race in American education. New Haven, CT: Yale University Press.

Labaree, D. F. (2012). Someone has to fail: The zero-sum game of public schooling. Cambridge, MA: Harvard University Press.

Leathwood, C., \& Hutchings, M. (2003). Entry routes to higher education: Pathways, qualifications and social class. In L. Archer, M. Hutchings, \& A. Ross (Eds.), Higher education and social class: Issues of exclusion and inclusion (pp. 138-154). London, UK: Routledge Falmer.

Le Mens, G., Hannan, M. T., \& Pólos, L. (2014). Organizational obsolescence, drifting tastes, and age dependence in organizational life chances. Organization Science, 26(2), $550-570$.

Levy, D. C. (2006). How private higher education's growth challenges the new institutionalism. In H. D. Meyer \& B. Rowan, The new institutionalism in education (pp. 143-162). Albany, NY: State University of New York Press. 
McMaster University. (2006, November 2). Maclean's releases annual rankings. Daily News. Retrieved from http://dailynews.mcmaster.ca/worth-mentioning/macleansreleases-annual-rankings/

Meyer, H. D. (2002). From "loose coupling" to "tight management"? Making sense of the changing landscape in management and organization theory. Journal of Educational Administration, 4O(6), 515-520.

Meyer, J. W., \& Rowan, B. (1977). Institutionalized organizations: Formal structure as myth and ceremony. American Journal of Sociology, 83(2), 340-363.

Ministry of Training, Colleges and Universities (MTCU). (2005). Ontario: A leader in learning. Retrieved from http://www.tcu.gov.on.ca/eng/document/reports/postsec.pdf

Ministry of Training, Colleges and Universities (MTCU). (2009). A manual governing the distribution of Ontario government operating grants to Ontario universities and university-related institutions (formula manual). Retrieved from https://www.uoguelph. ca/analysis_planning/images/pdfs/2009-10-Operating-Manual-Septo9.pdf

Ministry of Training, Colleges and Universities (MTCU). (2013). Ontario's differentiation policy framework for postsecondary education. Retrieved from http:// www.tcu.gov.on.ca/pepg/publications/PolicyFramework_PostSec.pdf

Mizruchi, M., \& Fein, L. (1999). The social construction of organizational knowledge: A study of the uses of coercive, mimetic, and normative isomorphism. Administrative Science Quarterly, 44(4), 653-683.

Morrill, C., \& McKee, C. (1993). Institutional isomorphism and informal social control: Evidence from a community mediation center. Social Problems, 4O(4), 445-463.

Mullen, A. (2010). Degrees of inequality: Culture, class, and gender in American higher education. Baltimore, MD: Johns Hopkins University Press.

Nelson, R., \& Winters, S. (1982). An evolutionary theory of economic change. Cambridge, MA: Harvard University Press.

Oliver, C. (1991). Strategic responses to institutional processes. Academy of Management Review, 16(1), 145-179.

Oliver, C. (1992). The antecedents of deinstitutionalization. Organization Studies, 13(4), 563-588.

Pfeffer, J. \& Salancik, G. (1978). The external control of organizations: A resource dependence perspective. New York, NY: Harper \& Row.

Pizarro Milian, R., \& Hicks, M. (2014). Ontario private career colleges: An exploratory analysis. Toronto, ON: Higher Education Quality Council of Ontario.

Pringle, J., \& Huisman, J. (2011). Understanding universities in Ontario, Canada: An industry analysis using Porter's five forces framework. Canadian Journal of Higher Education, 41(3), 36-58.

Quirke, L. (2013). Rogue resistance: Sidestepping isomorphic pressures in a patchy institutional field. Organization Studies, 34(11), 1675-1699.

Ravasi, D., \& Verona, G. (2001). Organising the process of knowledge integration: The benefits of structural ambiguity. Scandinavian Journal of Management, 17(1), 41-66. 
Sauder, M., \& Espeland, W. N. (2006). Strength in numbers-the advantages of multiple rankings. Indiana Law Journal, 81, 205-227.

Sauder, M., \& Espeland, W. N. (2009). The discipline of rankings: Tight coupling and organizational change. American Sociological Review, 74(1), 63-82.

Sauder, M., \& Lancaster, R. (2006). Do rankings matter? The effects of US News \& World Report rankings on the admissions process of law schools. Law \& Society Review, 4O(1), 105-134.

Scott, W. R. (2008). Institutions and organizations: Ideas and interests. Thousand Oaks, CA: Sage Publications.

Scott, W. R. (2010). Higher education in America: An institutional field approach. Working Paper. Retrieved from https://cepa.stanford.edu/sites/default/files/ ScottWRichard.pdf

Shanahan, T., \& Jones, G. A. (2007). Shifting roles and approaches: Government coordination of post $\square$ secondary education in Canada, 1995-2006. Higher Education Research \& Development, 26(1), 31-43.

Simon, H. A. (2000). Bounded rationality in social science: Today and tomorrow. Mind \& Society, 1(1), 25-39.

Skolnik, M. L. (2010). Quality assurance in higher education as a political process. Higher Education Management and Policy, 22(1), 67-86.

Skolnik, M. L. (2013). An historical perspective on the idea of institutional diversity and differentiation in Ontario higher education. College Quarterly, 16(2). Retrieved from http://collegequarterly.ca/2013-vol16-numo2-spring/skolnik.html

Snowdown and Associates. (2009). Revisiting Ontario college and university revenue data. Toronto, ON: Higher Education Quality Council of Ontario.

Spiegler, R. (2011). Bounded rationality and industrial organization. Oxford, UK: Oxford University Press

Stevens, M. L. (2009). Creating a class: College admissions and the education of elites. Cambridge, MA: Harvard University Press.

Stevens, M. L., Armstrong, E. A., \& Arum, R. (2008). Sieve, incubator, temple, hub: Empirical and theoretical advances in the sociology of higher education. Annual Review of Sociology, 34, 127-151.

Stuber, J. M. (2011). Inside the college gates: How class and culture matter in higher education. Lanham, MD: Lexington Books.

Tuchman, G. (2009). Wannabe U: Inside the corporate university. Chicago, IL: University of Chicago Press.

Tyack, D., \& Cuban, L. (1995). Tinkering toward utopia: A century of school reform. Cambridge, MA: Harvard University Press.

Weick, K. (1976). Educational organizations as loosely coupled systems. Administrative Science Quarterly, 21(1), 1-19. 
Weingarten, H. P., \& Deller, F. (2010). The benefits of greater differentiation ofOntario's university sector: Final report. Toronto, ON: Higher Education Quality Council of Ontario.

Weingarten, H. P., Hicks, M., Jonker, L., \& Liu, S. (2013). The Diversity of Ontario's Universites: A Data Set to Inform the Differentiation Discussion. Toronto, ON: Higher Education Quality Council of Ontario.

Wolf, A. (2003). Does education matter?: Myths about education and economic growth. London, UK: Penguin.

Wolf, A. (2011). Review of vocational education - The Wolf Report. London, UK: Department for Education. Retrieved from https://www.gov.uk/government/uploads/ system/uploads/attachment_data/file/180504/DFE-00031-2011.pdf

\section{Contact Information}

Roger Pizarro Milian

Department of Sociology

McMaster University

pizarrr@mcmaster.ca

Roger Pizarro Milian is a PhD candidate in the Department of Sociology at McMaster University. He specializes in the areas of organizational theory and the sociology of education.

Scott Davies is Canada Research Chair in Data, Equity and Policy in Education, and Professor of Policy and Leadership in Education at the University of Toronto. He has published many articles on educational inequality, politics, and organization, and is co-author of three editions of The Schooled Society. He is currently studying student learning and attainment trajectories over lengthy spans of time.

David Zarifa is Canada Research Chair in Life Course Transitions in Northern and Rural Communities and Associate Professor of Sociology at Nipissing University. His previous work has examined inequalities relating to post-secondary access, school-to-work transitions, workforce outcomes, and literacy and skills. He is currently examining the educational and employment outcomes of disadvantaged youth. 